\title{
Rider Revisited
}

BY H. WILLIAM AXFORD

$I^{N}$ 1940 Fremont Rider, then librarian of Wesleyan University, published a study which showed that, taken as a whole and on the average, American college and university libraries tended to double their holdings every fifteen years. ${ }^{1}$ Given the facts that in 1900 Harvard University was the only university in the United States possessing over 500,000 volumes in its library and that there were 25 universities listing over a million volumes in their libraries by 1960 , it seems appropriate to check and see how far Rider's axiom of library growth is still operative.

In the accompanying table are listed the university libraries with over a million volumes in 1960 , their holdings in 1946, the number of volumes added during the fifteen-year period, and the percentage increase in library holdings. While it is not fair to say that acquisition statistics are wholly unreliable, they should be considered as approximate rather than 100 per cent correct. The figures are taken from the Library Statistics of Colleges and Universities: 1959-60 published by the U.S. Office of Education, and from the July 1947 issue of $\mathrm{Col}$ lege and Research Libraries and the 1945 edition of the American Library Directory.

As can be seen in Table 1, only four universities out of the 25, the University of California at Berkeley, Wisconsin, UCLA and Indiana, increased their holdings 100 per cent or more between 1945 and 1960. Furthermore, the over-all aver-

\footnotetext{
1 Rider, Fremont, "The Growth of American College and University Libraries and Wesleyan's," About Books, Vol. XI, No. 1 (1940), 1-11.
}

Mr. Axford is Assistant Director of Libraries, University of Denver.

age percentage increase fell short of Rider's figure by 22 per cent. These figures seem to indicate that the validity of Rider's axiom tends to decrease the larger a library's holdings become. However, given the rise in book costs during these years, it is remarkable that the percentage increase in holdings of the 25 largest university libraries in the United States was as high as 78 per cent during this period.

Rider drew one other axiom from his study of the growth of college and university libraries:

Whenever the growth of any library has slackened you will always find that its college has been slipping; and the other hand, if any library has spurted ahead of the 15 year average during any decade, you will find on investigation that during that decade, its college, for some reason, has been taking on a new lease of life. In fact, we may assert as also axiomatic: unless a college or university is willing to be stagnant, willing not to maintain its place in the steady flow of cultural development, it seems to be inevitable that it must double its library in size every fifteen or twenty years. ${ }^{2}$

Whether or not there is a direct and clear-cut relationship between the size and rate of acquisition of the library and the quality of education offered by the

\footnotetext{
2 Ibid., p. 11.
} 
TABLE 1

\begin{tabular}{|c|c|c|c|c|}
\hline Institution & $\begin{array}{l}\text { Total Library } \\
\text { Holdings } 1946\end{array}$ & $\begin{array}{l}\text { Total Library } \\
\text { Holdings } 1960\end{array}$ & $\begin{array}{l}\text { Total Volumes } \\
\text { Added }\end{array}$ & $\begin{array}{l}\text { Percentage } \\
\text { Increase }\end{array}$ \\
\hline 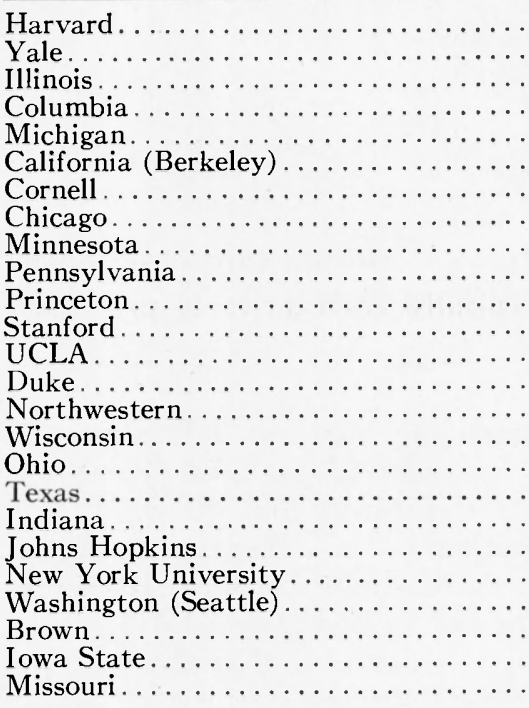 & $\begin{array}{r}4,804,968 \\
3,539,596 \\
2,003,622 \\
1,778,058 \\
1,267,518 \\
1,378,602 \\
1,094,117 \\
1,498,889 \\
1,422,529 \\
997,929 \\
1,058,920 \\
897,658 \\
504,941 \\
740,493 \\
788,832 \\
567,000 \\
688,900 \\
801,637 \\
617,947 \\
703,912 \\
668,795 \\
594,320 \\
665,041 \\
374,796 \\
525,557\end{array}$ & $\begin{array}{l}6,697,111 \\
4,394,988 \\
3,288,158 \\
2,875,761 \\
2,818,341 \\
2,503,060 \\
2,161,230 \\
2,094,824 \\
1,968,101 \\
1,665,114 \\
1,626,537 \\
1,592,287 \\
1,464,308 \\
1,435,164 \\
1,429,431 \\
1,384,222 \\
1,369,348 \\
1,350,671 \\
1,317,269 \\
1,159,747 \\
1,067,946 \\
1,060,086 \\
1,025,479 \\
1,021,441 \\
1,002,263\end{array}$ & $\begin{array}{r}1,892,142 \\
855,392 \\
1,204,539 \\
1,097,703 \\
1,550,823 \\
1,124,458 \\
1,067,113 \\
595,935 \\
545,572 \\
667,185 \\
567,617 \\
694,629 \\
959,367 \\
694,671 \\
640,599 \\
817,222 \\
680,448 \\
549,034 \\
699,322 \\
455,835 \\
399,151 \\
465,766 \\
360,438 \\
646,645 \\
476,806\end{array}$ & $\begin{array}{r}44 \\
24 \\
64 \\
60 \\
122 \\
81 \\
97 \\
40 \\
38 \\
66 \\
53 \\
77 \\
190 \\
93 \\
82 \\
144 \\
98 \\
68 \\
113 \\
65 \\
59 \\
78 \\
54 \\
58 \\
90\end{array}$ \\
\hline Average... & & & & $78 \%$ \\
\hline
\end{tabular}

TABLE 2

\begin{tabular}{|c|c|c|c|c|}
\hline Institution & $\begin{array}{l}\text { Total Library } \\
\text { Holdings } 1946\end{array}$ & $\begin{array}{l}\text { Total Library } \\
\text { Holdings } 1960\end{array}$ & $\begin{array}{l}\text { Total Volumes } \\
\text { added 1946-60 }\end{array}$ & $\begin{array}{l}\text { Percentage } \\
\text { Increase }\end{array}$ \\
\hline 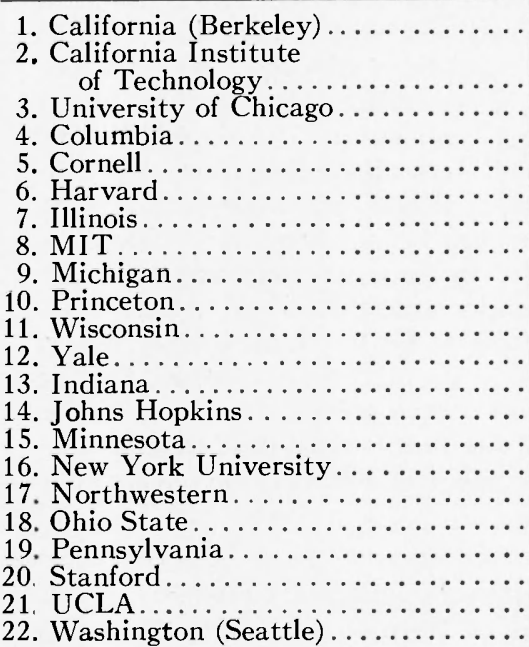 & $\begin{array}{r}1,378,602 \\
57,610 \\
1,498,889 \\
1,778,058 \\
1,094,117 \\
4,804,968 \\
2,003,622 \\
385,000 \\
1,267,518 \\
1,058,920 \\
567,000 \\
3,539,596 \\
617,947 \\
703,912 \\
1,422,529 \\
668,795 \\
788,832 \\
688,900 \\
997,929 \\
897,658 \\
504,941 \\
594,320\end{array}$ & $\begin{array}{r}2,503,060 \\
121,439 \\
2,094,824 \\
2,875,761 \\
2,161,230 \\
6,697,111 \\
3,288,158 \\
704,955 \\
2,818,341 \\
1,626,537 \\
1,384,222 \\
4,394,988 \\
1,317,269 \\
1,159,747 \\
1,968,101 \\
1,067,946 \\
1,429,431 \\
1,369,348 \\
1,665,114 \\
1,592,287 \\
1,464,308 \\
1,060,086\end{array}$ & $\begin{array}{r}63,829 \\
595,935 \\
1,077,703 \\
1,781,644 \\
1,892,143 \\
1,284,536 \\
319,955 \\
1,550,823 \\
567,617 \\
817,222 \\
855,392 \\
699,322 \\
455,828 \\
545,572 \\
399,151 \\
650,599 \\
680,448 \\
667,185 \\
694,629 \\
959,367 \\
594,320\end{array}$ & $\begin{array}{r}112 \\
40 \\
60 \\
97 \\
44 \\
64 \\
83 \\
122 \\
53 \\
144 \\
24 \\
113 \\
65 \\
38 \\
59 \\
82 \\
98 \\
66 \\
77 \\
190 \\
78\end{array}$ \\
\hline & & & & $80 \%$ \\
\hline
\end{tabular}


university is somewhat difficult to demonstrate. This is at least partly true because the quality of education offered by any given institution is a matter of subjective judgment. However, in 1960 Bernard Berelson published a book called Graduate Education in the United States which contains the results of one survey which can be helpful. ${ }^{3}$ In this survey, Berelson asked 92 graduate deans and 92 graduate faculties to list those universities, which in their opinion, were the top graduate institutions in the country. Table 2 shows the 22 institutions most often mentioned, in order of frequency, their library holdings in 1946 and in 1960, and the percentage increase in holdings during this fifteen-year period.

The degree of correspondence be-

3 Berelson, Bernard, Graduate Education in the United States (New York: McGraw-Hill, 1960), p. 280. tween the institutions appearing in the tables would seem to have some significance. Missing from Berelson's list of 22 top graduate institutions are only five of the 25 universities in the United States that have book stocks of over a million volumes: Texas, Brown, Iowa State, Duke, and Missouri. From this it would seem that Rider's emphasis on the relationship between the rate of growth of the university library and the over-all quality of the educational program is still essentially correct. It is probable, however, that the percentage rate of growth of the largest university libraries will continue to decline, even though the total number of new volumes added each year will continue to increase, and that only a few of the largest university libraries will be able to double their collections every fifteen years.

\section{CUSHING-MALLOY, INC. I350 North Main Street P.O. Box II87 Ann Arbor, Michigan}

\section{Printers of ACRL Monographs}

\section{I T H O P R I N T E R S}

Known for

QUALITY-ECONOMY-SERVICE

Let us quote on your next printing 